\title{
Analysis of the utilization and cost of antibiotics at an intensive care unit in Surabaya
}

\section{Analisis penggunaan dan biaya antibiotik di ruang rawat intensif sebuah Rumah Sakit di Surabaya}

\author{
Felix Hidayat $^{1}$, Adji Prayitno Setiadi ${ }^{1,2}$, Eko Setiawan ${ }^{* 1,2}$ \\ ${ }^{1}$ Departemen Farmasi Klinis dan Komunitas \\ ${ }^{2}$ Pusat Informasi Obat dan Layanan Kefarmasian (PIOLK) \\ Fakultas Farmasi, Universitas Surabaya \\ Raya Kalirungkut Surabaya, 60293
}

\begin{abstract}
ABSTRAK
Ketepatan penggunaan antibiotik termasuk ketercampuran (compatibility) terhadap sediaan lain merupakan faktor penentu efektivitas dan biaya terapi antibiotik pada pasien intensive care unit (ICU). Penelitian ini bertujuan untuk mengkaji profil penggunaan, ketepatan, biaya, dan kompatibiltas penggunaan antibiotik pada pasien yang mendapat perawatan di ICU sebuah rumah sakit di Surabaya selama periode November-Desember 2015. Penelitian ini merupakan penelitian observasional prospektif dengan menggunakan rekam medis sebagai bahan utama pengambilan data. Seluruh data pasien ICU yang menggunakan antibiotik dan memenuhi kriteria inklusi dan eksklusi dianalisis secara deskriptif. Total terdapat data dari 42 orang pasien yang dianalisis pada penelitian ini. Penggunaan antibiotik terdiri dari 46 penggunaan (65,71\%) antibiotik tunggal dan 24 penggunaan $(34,29 \%)$ antibiotik kombinasi. Jenis antibotik tunggal yang paling banyak digunakan adalah ceftriaxone $(43,48 \%)$ dan kombinasi antibiotik terbanyak adalah kombinasi ceftazidime dan levofloxacin $(12,50 \%)$. Terjadi 30 kali proses pergantian terapi yang didominasi oleh proses eskalasi $(43,34 \%)$ dan tidak ditemukan $(0,00 \%)$ proses pergantian rute terapi dari rute intravena ke per-oral. Dari seluruh pasien dengan diagnosis infeksi, hanya 4 dari 15 orang pasien terdiagnosis infeksi $(26,67 \%)$ yang mendapatkan terapi antibiotik yang tepat secara keseluruhan, dan 13,96\% campuran antibiotik dengan sediaan intravena lain masih dinyatakan belum memiliki informasi terkait status ketercampurannya. Rata-rata biaya yang dikeluarkan pasien untuk antibiotik sebesar Rp. 459.492 (min-max: Rp 15.852,to $\operatorname{Rp} 8.314 .914,-)$.
\end{abstract}

Kata kunci: antibiotik, intensive care, resistensi, biaya antibiotik

\begin{abstract}
The appropriateness of antibiotic utilization including the compatibility when it was mixed with other pharmaceutical products are important factors determining the effectiveness and cost of antibiotics treatment among patients admitted to the intensive care unit (ICU). The aim of this research was to figure out the antibiotics utilization, appropriateness, cost, and compatibility profile given to the inpatients of the intensive care unit in one hospital in Surabaya during November-December 2015. This research was prospective observational study using medical records as source of information.
\end{abstract}

\footnotetext{
Penulis korespondesi:

Eko Setiawan

Departemen Farmasi Klinis dan Komunitas, Fakultas Farmasi, Universitas Surabaya

Raya Kalirungkut Surabaya, 60293

Email: ekosetiawan.apt@gmail.com
} 
All patients' data receiving antibiotics that met the inclusion and exclusion criteria was collected and analyzed descriptively. There were 42 patients participated in this research. Analysis of antibiotic utilization profile revealed 46 usage $(65.71 \%)$ of single antibiotics and 24 usage $(34.29 \%)$ of combination antibiotics. The most frequently used of antibiotic in single usage was ceftriaxone $(43.48 \%)$ while in combination were ceftazidime and levofloxacin (12.50\%). There were 30 antibiotics treatment changes that $43.34 \%$ was classified as escalation process and there was no (0\%) any switching from intravenous to oral therapy. Only 4 out of 15 patients with infection related diagnosis (26.67\%) got appropriate antibiotic treatment. Moreover, result from compatibility analysis found that $13.96 \%$ admixtures between antibiotics and other intravenous pharmaceutical products did not have clear compatibility status. The average of antibiotic cost per-patient was Rp. 459.492 (min-max: Rp 15.852,- to Rp 8.314.914,-).

Keywords: antibiotics, intensive care, resistance, antibiotic cost

\section{PENDAHULUAN}

Ketepatan penggunaan antibiotik pada pasien di ruang ICU (Intensive Care Unit) perlu mendapatkan perhatian lebih karena mempengaruhi luaran (outcome) klinis pasien (Khan et al., 2015; Marquet et al., 2015). Jaminan ketepatan penggunaan antibiotik pada kelompok pasien yang mendapat perawatan di ICU semakin penting untuk dipastikan dengan mempertimbangkan perbedaan kondisi klinis kelompok pasien tersebut dibandingkan dengan pasien yang mendapatkan perawatan di ruang lain. Umumnya, ICU merupakan tempat perawatan bagi pasien dengan keadaan kritis (critically ill) kecuali apabila dalam setting tertentu dengan keterbatasan tempat perawatan, pasien kritis terpaksa mendapatkan perawatan di bangsal non-ICU. Pasien dengan keadaan kritis memiliki kondisi patofisiologis yang berbeda dibandingkan dengan kelompok pasien non-kritis, dan perbedaan kondisi patofisiologis tersebut dapat berdampak pada perbedaan profil farmakokinetik obat dalam tubuh pasien kritis, termasuk profil farmakokinetik antibiotik (Goncalves-Pereira \& Povoa, 2011). Perubahan profil farmakokinetik yang paling menonjol adalah perubahan pada volume distribusi (Vd) obat larut air dan klirens ginjal $(\mathrm{Cl})$. Pada pasien kritis, umumnya, $\mathrm{Vd}$ lebih besar dan $\mathrm{Cl}$ akan meningkat nilainya dibandingkan dengan pasien non-kritis. Adanya perubahan nilai $\mathrm{Vd}$ dan $\mathrm{Cl}$ tersebut dapat menyebabkan turunnya konsentrasi obat dalam darah, tanpa terkecuali juga pada penggunaan antibiotik. Hal tersebut dapat berpengaruh pada kegagalan mencapai minimum inhibitory concentration (MIC) yang mutlak diperlukan dalam proses eradikasi bakteri.

Beberapa konsekuensi dari eradikasi bakteri yang tidak optimal dapat dirasakan baik dari segi kesehatan, sosial maupun ekonomi. Resistensi merupakan konsekuensi terbesar dalam bidang kesehatan dari kegagalan melakukan eradikasi bakteri secara sempurna. Sebuah penelitian terpublikasi yang dilakukan di ICU sebuah rumah sakit di Bucharest, Rumania menunjukkan bahwa beberapa mikroorganisme mempunyai tingkat resistensi terhadap antibiotik yang lebih tinggi di ICU dibandingkan ruang rawat lain (Cucu et al., 2014). Peningkatan kasus infeksi yang disebabkan oleh bakteri yang resisten dapat berdampak pada peningkatan mortalitas, morbiditas dan biaya kesehatan. Sebuah penelitian membuktikan bahwa pasien ICU yang mengalami infeksi oleh Methicillin Resistant Staphylococcus aureus (MRSA) memiliki tingkat kematian yang lebih tinggi daripada pasien yang mengalami infeksi Methicillin Suceptible Staphylococcus aureus (MSSA), yaitu sebesar 29,10\% berbanding 20,50\% ( $\mathrm{P}<0.01)$ (Hanberger et al., 2011). Penelitian lain yang dilakukan di Spanyol tahun 2010 memaparkan sebuah fakta terkait peningkatan biaya pada kasus infeksi oleh bakteri yang resisten disebabkan oleh beberapa hal dan salah satunya adalah bertambahnya lama tinggal di rumah sakit. Pasien dengan bakterimia harus mengeluarkan biaya sebesar $€ 11.044,59$ berbanding $€ 9.839,52$ apabila terinfeksi oleh MRSA dan tanpa MRSA, secara berturut-turut (Rubio-Terres et al., 2010). Berdasarkan fakta di atas dapat disimpulkan bahwa resistensi antibiotik dapat memberikan pengaruh yang besar terhadap kondisi klinis pasien dan biaya pengobatan.

Selain perbedaan kondisi klinis yang dapat berkontribusi pada tidak optimalnya proses eradikasi bakteri, pemberian antibiotik bersama dengan sediaan intravena lain yang tidak kompatibel dapat 
menjadi faktor penting lain penyebab turunnya efektivitas antibiotik terapi. Pemberian antibiotik bersama dengan sediaan intravena lain yang tidak kompatibel dapat menyebabkan terjadinya endapan, perubahan warna, pembentukan kristal, dan penurunan konsentrasi obat yang pada akhirnya berpotensi menurunkan efektivitas terapi antibiotik. Sebagai contoh adalah penggunaan meropenem bersama dengan pantoprazole dalam syringe yang sama akan menyebabkan pembentukan endapan dalam waktu 15 menit (Trissel, 2013).

Secara finansial, penggunaan antibiotik yang tidak tepat, terlepas dari besarnya kontribusi resistensi, juga berdampak secara langsung terhadap peningkatan biaya kesehatan. Beberapa praktek berikut dapat diklasifikasikan sebagai praktek penggunaan antibiotik yang tidak tepat, antara lain: pemberian antibiotik pada kasus yang seharusnya tidak memerlukan antibiotik dan penggunaan antibiotik melebihi dari regimen pemberian yang direkomendasikan. Praktek tersebut meningkatkan jumlah volume penggunaan yang berdampak langsung pada biaya kesehatan. Fenomena tersebut harus diwaspadai oleh berbagai pihak di Indonesia terutama dalam era implementasi Jaminan Kesehatan Nasional (JKN) yang telah dimuali sejak tahun 2014.

Sampai saat ini penelitian mengenai profil penggunaan antibiotik di ruangan Intensive Care rumah sakit di Indonesia yang meliputi profil penggunaan, kesesuaian, kompatibilitas dan biaya belum banyak dilakukan. Dengan mempertimbangkan pentingnya jaminan ketepatan pemberian terapi antibiotik pada kelompok pasien yang memiliki perbedaan profil farmakokinetik tersebut, besarnya potensi pemberian bersamaan dengan sediaan intravena lain yang tidak kompatibel, dan besarnya potensi peningkatan biaya kesehatan akibat penggunaan antibiotik yang tidak tepat, maka analisis kesesuaian antibiotik dilihat dari sudut pandang baik jenis, dosis, dan waktu, serta analisis kompatibilitas dan biaya perlu dilakukan sebagai upaya untuk mengoptimalkan tercapainya hasil terapi yang baik bagi pasien dan mencegah pemborosan anggaran kesehatan nasional di era implementasi JKN. Oleh karena itu, penelitian ini bertujuan untuk mengkaji profil penggunaan, ketepatan, biaya, dan kompatibilitas penggunaan antibiotik pada pasien yang mendapat perawatan di ICU.

\section{METODE PENELITIAN}

Penelitian ini merupakan penelitian deskiptif observasional yang dilakukan secara prospektif. Ijin pelaksanaan penelitian didapatkan dari pihak rumah sakit melalui Surat No. 070/14640/436.7.8/2015. Populasi yang digunakan adalah pasien yang menggunakan antibiotik dan mendapatkan perawatan di ruang Intensive Care Unit (ICU) dan Intensive Cardiac Care Unit (ICCU) di sebuah rumah sakit milik pemerintah Kota Surabaya selama periode November-Desember 2015. Pada rumah sakit tempat pengambilan data, ICU tidak hanya digunakan untuk merawat pasien dewasa tetapi juga pasien anak-anak. Populasi dalam penelitian ini adalah seluruh pasien, baik dewasa maupun anak-anak, yang mendapatkan antibiotik di ICU selama bulan November 2015-Desember 2015. Sampel dalam penelitian ini adalah keseluruhan populasi.

Proses pengambilan data dilakukan dengan cara pencatatan data pasien yang terdapat pada rekam medis, pengamatan langsung terhadap pasien, dan bertanya kepada perawat. Parameter yang diamati, antara lain: (1) karakteristik pasien (umur, jenis kelamin, lama perawatan, diagnosis dokter, hasil pemeriksaan laboratorium dan pemeriksaan fisik, hasil kultur bakteri, hasil terapi setelah mendapat perawatan), (2) karakteristik antibiotik (golongan dan jenis, penggunaan antibiotik tunggal atau kombinasi, rute pemberian, dosis, frekuensi, lama pemberian per-administrasi, durasi pemberian selama perawatan, biaya penggunaan antibiotik). Data yang didapat dianalisis dengan menggunakan nilai rata-rata/mean $(\bar{x})$ dan/atau dengan menggunakan bentuk persentase (\%). Diagnosis pasien pada penelitian ini dibagi menjadi 3 bagian, yaitu: (1) diagnosis masuk, (2) diagnosis kerja, dan (3) diagnosis keluar.

Analisis profil penggunaan antibiotik pada penelitian ini dilakukan dengan mengkaji proses pergantian terapi antibiotik dan biaya antibiotik. Proses pergantian terapi antibiotik pada penelitian ini digolongan menjadi 3, yaitu: (1) proses eskalasi, (2) proses de-eskalasi, dan (3) proses pergantian rute terapi dari intravena menjadi per-oral (IV to oral). Proses eskalasi didefinisikan sebagai suatu proses ditambahkannya antibiotik pada terapi sebelumnya ataupun digantinya suatu antibiotik dengan antibiotik lain dengan coverage yang lebih luas. Suatu proses pergantian terapi disebut proses de- 
eskalasi bila dilakukan beberapa hal sebagai berikut: (1) pergantian antibiotik dari broad spectrum ke narrow spectrum, (2) pengurangan jumlah antibiotik yang digunakan, (3) penurunan dosis antibiotik, (4) penurunan frekuensi pemberian antibiotik, dan (5) penghentian terapi antibiotik. Perubahan terapi antibiotik yang dilakukan sebagai bentuk transisi proses pergantian terapi, yaitu terjadi hanya pada 1 hari pemberian, tidak diklasifikasikan sebagai eskalasi atau deeskalasi. Penggunaan kombinasi antibiotik golongan beta laktam dengan beta laktamase tidak diklasifikasikan sebagai bentuk kombinasi pada penelitian ini. Pada penelitian ini yang dimaksud dengan kombinasi antibiotik adalah penggunaan 2 antibiotik atau lebih yang digunakan dalam 1x24 jam. Biaya penggunaan antibiotik pada penelitian ini dihitung dengan menggunakan data billing yang dikeluarkan oleh pihak rumah sakit kepada pasien. Perspektif pasien digunakan sebagai dasar penghitungan biaya dan tidak dilakukan penyesuaian dengan menggunakan laju inflasi. Selain itu biaya penggunaan antibiotik juga dibandingkan terhadap tarif Indonesia Case Based Groups (INA-CBGs) pada pasien yang mendapatkan diagnosis infeksi.

Kesesuaian penggunaan antibiotik pada penelitian ini hanya dilakukan pada pasien yang mendapat diagnosis kerja atau keluar terkait infeksi saja dan pedoman terapi Infectious Disease Society of America (IDSA) terbaru akan digunakan sebagai pustaka utama untuk melakukan analisis kesesuaian penggunaan antibiotik. Literatur Drug Information Handbook edisi 22 tahun 2014 dan Pediatric \& Neonatal Dosage Handbook edisi 20 tahun 2013 digunakan sebagai acuan pendukung jika dibutuhkan informasi yang tidak dapat ditemukan pada pedoman terapi IDSA. Suatu pemberian antibiotik diklasifikasikan tepat secara keseluruhan apabila jenis, dosis, dan frekuensi pemberian antibiotik tersebut tepat seluruhnya. Pemberian antibiotik disebut tepat sebagian apabila diberikan jenis yang tepat dengan dosis atau frekuensi yang tidak tepat. Pemberian antibiotik dianggap tidak tepat jika jenis antibiotik yang diberikan tidak tepat walaupun dosis dan frekuensi yang diberikan tepat. Analisis kesesuaian pada pasien dengan diagnosis infeksi lebih dari 1 jenis akan dilakukan untuk setiap diagnosis infeksi yang ada. Diagnosis yang digunakan unntuk analisis kesesuaian adalah diagnosis masuk dan diagnosis kerja.

Analisis kompatibilitas sediaan parenteral akan dilakukan dengan memperhatikan pencampuran antara sediaan antibiotik dengan antibiotik lain, sediaan antibiotik dengan obat lain, dan sediaan antibiotik dengan pelarut. Pustaka acuan yaitu: (1) Handbook on Injectable Drugs edisi 17 tahun 2013 dan (2) brosur sediaan antibiotik terkait, digunakan sebagai acuan utama proses analisis kompatibilitas dan inkompatibilitas. Hasil analisis digolongkan dalam beberapa kelompok, antara lain: kompatibel (K), inkompatibel (I), No Information (NI), dan Not Applicable (NA). Pembuatan kesimpulan klasifikasi tersebut didasarkan dengan kriteria sebagai berikut: (1) campuran dinyatakan kompatibel apabila pada buku referensi dan/atau brosur disimpulkan dengan jelas campuran tersebut K, (2) campuran dinyatakan inkompatibel apabila pada buku referensi dan/atau brosur disimpulkan dengan jelas campuran tersebut I, (3) campuran dinyatakan NI apabila pada buku referensi dan brosur tidak ditemukan informasi mengenai profil kompatibilitas campuran tersebut, (4) campuran dinyatakan NA apabila pada buku referensi dan brosur terdapat perbedaan informasi.

\section{HASIL DAN PEMBAHASAN}

Pada penelitian ini terdapat 42 pasien di ruang ICU/ICCU yang memenuhi kriteria inklusi. Jumlah pasien laki-laki lebih banyak daripada pasien perempuan yaitu sebanyak 23 pasien $(54,76 \%)$ berbanding 19 pasien $(45,24 \%)$. Rata-rata usia pasien adalah 39,67 $\pm 20,94$ tahun. Detail informasi terkait karakteristik pasien dapat dilihat pada Tabel I.

Diagnosis keluar pasien dalam penelitian ini mempunyai hasil yang sama dengan diagnosis kerja. Dari total 42 pasien, hanya 15 pasien $(35,71 \%)$ yang mendapatkan diagnosis keluar infeksi, sedangkan 27 pasien $(64,29 \%)$ lainnya tidak memiliki diagnosis infeksi. Dari total 15 pasien dengan diagnosis infeksi, hanya 11 pasien $(73,33 \%)$ yang mendapatkan diagnosis masuk infeksi sedangkan 4 pasien $(26,67 \%)$ sisanya masuk ruang ICU/ICCU tanpa diagnosis masuk infeksi. Dari total 27 pasien yang tidak memiliki diagnosis infeksi, semua pasien mempunyai tanda-tanda infeksi seperti peningkatan 
nilai white blood cell (WBC), suhu badan, denyut nadi ataupun respiratory rate. Detail dari seluruh diagnosis pasien dapat dilihat pada Tabel II.

Tabel I. Data karakteristik pasien yang mendapatkan antibiotik di ruang ICU dan ICCU

\begin{tabular}{lcc}
\hline \multicolumn{1}{c}{ Karakteristik Pasien } & Nilai & Persentase $(\boldsymbol{\%})$ \\
\hline Jumlah Pasien & & 100,00 \\
Total pasien & 42 & 80,96 \\
$\quad$ Dewasa & 34 & 19,04 \\
$\quad$ Anak-anak & 8 & 71,43 \\
Pasien ICU & 30 & 28,57 \\
$\quad$ Pasien ICCU & 12 & - \\
Usia Pasien (mean \pm SD), & & \\
$\quad$ Total pasien (tahun) & $39,67 \pm 20,94$ [Min-maks:1-85] \\
$\quad$ Pasien ICU (tahun) & $36,77 \pm 21,29$ [Min-maks: $1-85]$ & 54,76 \\
$\quad$ Pasien ICCU (tahun) & $46,92 \pm 18,95$ [Min-maks: 20-81] & 45,24 \\
Jenis Kelamin (orang) & & 23 \\
$\quad$ Laki-laki & 19 & \\
$\quad$ Perempuan & & \\
\hline
\end{tabular}

Keterangan Tabel I

i. Kepanjangan dari singkatan dalam tabel: ICU: Intensive Care Unit; ICCU: Intensive Cardiac Care Unit.

Berdasarkan jenisnya, terdapat 6 golongan antibiotik yang digunakan sebagai terapi dalam penelitian ini, antara lain: (1) penicillin (+ kombinasi dengan Anti $\beta$-lactamases, seperti clavulanic acid ataupun sulbactam), (2) cephalosporins, (3) carbapenems, (4) floroquinolones, (5) aminoglycosides, dan (6) nitroimidazoles. Ceftriaxone adalah jenis antibiotik yang paling banyak digunakan sebagai terapi tunggal yaitu sebesar 20 kali pemakaian $(43,48 \%)$. Hasil pada penelitian ini tidak berbeda dengan penelitian yang dilakukan oleh Luciana et al. (2015) di salah satu rumah sakit di Jakarta, dari total 805 resep terapi antibiotik empirik di sebuah ICU, 281 resep $(34,91 \%)$ diantaranya menggunakan Ceftriaxone. Walaupun efektivitas dan keamanannya baik, bukan berarti penggunaan Cefrtiaxone tanpa risiko. Sebuah kajian yang dipublikasikan pada tahun 2008 menunjukkan bahwa penggunaan ceftriaxone berhubungan dengan gangguan flora normal yang terdapat di intestinal dan peningkatan risiko terjadinya infeksi oleh Clostridium defficile (Owens et al., 2008). Beberapa penelitian mengaitkan penggunaan ceftriaxone dengan gangguan pada sistem pencernaan (Owens et al., 2008; Marcon et al., 2006). Selain dihadapkan pada masalah seperti di atas, masalah terbesar yang harus diwaspadai adalah masalah resistensi yang memburuk. Sebuah penelitian yang dilakukan di ICU Rumah Sakit Fatmawati, Jakarta, menunjukkan bahwa bakteri yang telah diisolasi banyak yang telah resisten terhadap antibiotik cephalosporins generasi ke tiga. Ceftriaxone, ditemukan resisten terhadap 60,9\% isolat Pseudomona aeruginosa dan 75,7\% isolat Klebsiella pneumoniae (Radji et al., 2011).

Antibiotik yang digunakan pada penelitian ini tidak hanya antibiotik tunggal, melainkan juga antibiotik kombinasi. Terdapat 46 kali penggunaan antibiotik tunggal dan 24 kali penggunaan antibiotik kombinasi. Jenis dan golongan antibiotik yang digunakan dalam bentuk tunggal ditampilkan pada Tabel III. Jenis antibiotik yang digunakan dalam bentuk kombinasi adalah sebagai berikut: Metronidazole \& Ceftriaxone dan Ceftazidime \& Levofloxacin masing-masing 3 kali penggunaan; kombinasi Amoxicillin/clavulanic acid \& Levofloxacin sebanyak 2 kali penggunaan; kombinasi Meropenem \& Metronidazole, Ceftizoxime \& Levofloxacin, Ceftriaxone \& Ciprofloxacin, Ciprofloxacin \& Gentamycin, Ceftriaxone \& Gentamycin, Ceftriaxone \& Meropenem, Ciprofloxacin \& Metronidazole, Ceftriaxone \& Levofloxacin, Levofloxacin \& Meropenem \& Amikacin, Ceftizoxime \& Levofloxacin \& Meropenem, Ciprofloxacin \& Metronidazole \& Gentamicin, Cefuroxime \& Streptomycin \& Ceftriaxone, Metronidazole \& Cefazolin, Ceftriaxone \& Streptomycin, Cefuroxime \& Streptomycin, Amoxicillin/klavulanat \& Levofloxacin \& Meropenem \& Metronidazole masing-masing 1 kali penggunaan. 
Tabel II. Data diagnosis masuk, kerja, atau keluar terkait infeksi pada pasien ICU dan ICCU

\begin{tabular}{lcc}
\multicolumn{1}{c}{ Jenis Diagnosis } & \multicolumn{2}{c}{ Jumlah Pasien (orang) } \\
& Diagnosis Masuk & Diagnosis Kerja / Keluar \\
\hline Satu diagnosis & 7 & 7 \\
Pneumonia & 2 & 3 \\
Susp. Tuberkulosis & 1 & 1 \\
Spondilitis TB & 1 & 1 \\
Susp. Encephalitis & 1 & 1 \\
Susp. Pneumonia & 2 & 1 \\
Dua diagnosis & 2 & 5 \\
GEA \& Susp. BP & 1 & 1 \\
Susp. Sepsis \& encephalitis & 1 & 1 \\
Sepsis \& MODS & 0 & 1 \\
Sepsis \& Pneumonia & 0 & 2 \\
Tiga diagnosis & 2 & 2 \\
Susp. Sepsis, pneumonia \& infeksi & 1 & 1 \\
saluran kemih & & \\
Sepsis, Pneumonia, \& Sepsis & 1 & 1 \\
Empat diagnosis & 0 & 1 \\
meningoencephalitis, TB paru & & 15 \\
millier, limpadenitis TB \& sepsis & 0 & \\
Total & $\mathbf{1 1}$ & 1 \\
\hline Ketis
\end{tabular}

Keterangan Tabel II:

i. Kepanjangan dari singkatan pada tabel: TB: Tuberkulosis; GEA: Gastroenteritis akut; BP: Bronko Pneumonia; DHF: Dengue Haemorragic Fever; MODS: Multiple Organ Dysfunction Syndrome.

Penggunaan antibiotik kombinasi merupakan salah satu pilihan dalam pemberian terapi empirik infeksi pada pasien dengan keadaan kritis. Penggunan antibiotik kombinasi mempunyai beberapa keuntungan antara lain (1) meningkatkan luas cakupan eradikasi bakteri, (2) efek anti bakteri yang saling bersinergi, (3) mencegah terjadinya resistensi. Pemilihan kombinasi yang tepat akan menjadi hal yang krusial dalam meningkatkan efektivitas terapi (Vincent et al., 2016). Sebuah penelitian juga menunjukkan bahwa penggunaan kombinasi dua antibiotik atau lebih pada pasien dengan kondisi kritis yang mengalami carbapenem-resistant bacterimia berhubungan dengan penurunan risiko kematian (OR, 0.19 [95\% CI, 0.06-0.56]; P<0.01) (Bass et al., 2015). Namun demikian, bukan berarti bahwa setiap pasien ICU perlu mendapatkan terapi antibiotik kombinasi dengan mempertimbangkan beberapa kerugian dari penggunaan kombinasi antibiotik, antara lain (1) kemungkinan efek antagonis antar antibiotik, (2) kemungkinan terjadinya superinfeksi, (3) kemungkinan meningkatkan terjadinya resistensi, (4) peningkatan toksisitas, (5) peningkatan biaya. Pedoman terapi terkait identifikasi pasien yang perlu mendapatkan terapi antibiotik yang disepakati oleh profesi kesehatan lokal suatu rumah sakit perlu dibuat dan diterapkan sebagai upaya untuk meminimalkam penggunaan antibiotik kombinasi yang berlebihan (Vincent et al., 2016).

Dosis dan frekuensi penggunaan antibiotik dalam penelitian ini memiliki beberapa perbedaan terutama pada pasien di ruang ICU/ICCU (Tabel IV). Rata-rata durasi penggunaan antibiotik adalah sebesar 3,13 $\pm 1,19$ hari dengan cara pemberian yang sama pada setiap ruangan yaitu dengan iv intermittent. Lama pemberian sediaan parenteral kepada pasien ruang ICU setiap kali pemberian adalah selama 15-60 menit dan pelarut yang digunakan adalah PZ (NaCL 0,9\%). Pemberian antibiotik pada ruang ICCU dilakukan dengan menggunakan campuran 50\% pelarut PZ (NaCL 0,9\%) dan 50\% dengan menggunakan dextrose 5\%. Pemberian antibiotik di ruang ICCU dilakukan selama \pm 15 menit setiap kali pemberian. Cara pemberian antibiotik dalam penelitian ini, termasuk antibiotik golongan cephalosporins dan penicillin, baik di ICU ataupun ICCU, diberikan secara intravena (iv) intermittent dalam rentang waktu antara 15 hingga 60 menit. Kedua golongan antibiotik tersebut merupakan antibiotik dengan karakteristik time-dependent, yaitu suatu antibiotik yang efektivitas eradikasi 
bakterinya ditentukan berdasarkan lamanya konsentrasi antibiotika di dalam tubuh untuk tetap berada di atas Minimum Inhibitory Concebtration (MIC). Salah satu parameter farmakokinetikfarmakodinamik yang dapat digunakan sebagai indikator keberhasilan terapi untuk antibiotik timedependent adalah \%T/MIC (Roberts \& Lipman, 2009). Setiap antibiotik memiliki nilai \% T/MIC yang berbeda untuk jenis patogen yang berbeda pula. Sebagai contoh adalah antibiotik golongan betalaktam, sebuah penelitian menunjukkan bahwa dengan mempertahankan nilai T>MIC di angka 100\% maka dapat secara signifikan meningkatkan tingkat kesembuhan $(\mathrm{p}=0,002)$ dan eradikasi bakteri ( $<<0,001)$ (McKinnon et al., 2008). Sebuah penelitian oleh Dulhunty et al., (2013) menunjukkan pemberian antibiotik beta-laktam secara continous infusion dapat mengoptimalkan ketercapaian konsentrasi plasma di atas MIC dibandingkan pemberian secara intermittent infusion yang berdampak secara signifikan terhadap perbaikan klinis pasien. Dengan mempertimbangkan berbagai profil farmakokinetik dari berbagai antibiotik maka administrasi dari antibiotik harus menyesuaikan hal tersebut sehingga dapat mencapai efek terapeutik yang diinginkan.

Tabel III. Jenis dan golongan antibiotik pada penggunaan tunggal

\begin{tabular}{lcc}
\hline \multicolumn{1}{c}{ Antibiotik } & Penggunaan & Persentase (\%) \\
\hline Penicilin & 5 & 10,86 \\
Penicillin dengan inhibitor $\beta$-lactamases & 5 & 8,70 \\
- Amoxicillin-Clavulanic Acid & 4 & 2,17 \\
-Ampicillin-Sulbactam & 1 & \\
Cephalosporins & 30 & 4,35 \\
First-Generation Cephalosporins & 2 & 4,35 \\
-Cefazolin & 2 & 2,17 \\
Second-Generation Cephalosporins & 1 & 2,17 \\
-Cefuroxime & 1 & 58,70 \\
Third-Generation Cephalosporins & 27 & 43,48 \\
-Ceftriaxone & 20 & 2,17 \\
-Cefotaxime & 1 & 6,52 \\
- Ceftizoxime & 3 & 2,17 \\
- Ceftazidime & 1 & 4,35 \\
- Cefoperazone & 2 & \\
Carbapenems & 3 & 6,52 \\
- Meropenem & 3 & \\
Floroquinolons & 4 & 6,52 \\
- Levofloxacin & 3 & 2,17 \\
-Ciprofloxacin & 1 & \\
Nitroimidazole & 2 & 4,35 \\
- Metronidazole & 2 & 2,17 \\
Aminoglycoside & 2 & 100,00 \\
- Netilmicin & 1 & \\
-Amikacin & 1 & \\
Total & 46 & \\
\hline
\end{tabular}

Proses pergantian terapi terjadi pada 14 pasien dengan total terdapat 30 kali proses pergantian terapi, atau dengan kata lain seorang pasien dapat mengalami lebih dari 1 proses penggantian terapi. Proses de-eskalasi hanya terjadi sebanyak 4 kali $(13,33 \%)$ sedangkan proses eskalasi terjadi sebanyak 13 kali $(43,34 \%)$. Tidak terdapat satupun proses pergantian dari terapi iv ke oral selama proses pengambilan data. Sebanyak $12(40 \%)$ proses pergantian terapi diklasifikasikan sebagai proses transisi dan sebuah $(3,33 \%)$ proses pergantian terapi tidak dapat dikategorikan dalam klasifikasi apapun. 
Tabel IV. Data dosis antibiotik dan frekuensi pemberian pada pasien di ruang ICU dan ICCU

\begin{tabular}{|c|c|c|c|c|c|c|}
\hline \multirow[t]{2}{*}{ Antibiotik } & \multicolumn{3}{|c|}{ ICU } & \multicolumn{3}{|c|}{ ICCU } \\
\hline & Dosis (mg) & $\begin{array}{l}\text { Frekuensi } \\
\text { (kali/hari) }\end{array}$ & $\begin{array}{l}\text { Jumlah } \\
\text { (pasien) }\end{array}$ & Dosis (mg) & $\begin{array}{l}\text { Frekuensi } \\
\text { (kali/hari) }\end{array}$ & $\begin{array}{r}\text { Jumlah } \\
\text { (pasien) }\end{array}$ \\
\hline Amikacin & - & - & - & 500 & 2 & 1 \\
\hline Amoxicillin-Klavulanat & 1000 & 3 & 2 & 500 & 3 & 2 \\
\hline Ampicillin-Sulbactam & 1000 & 4 & 1 & - & - & - \\
\hline \multirow[t]{2}{*}{ Cefazolin } & 1000 & 2 & 1 & 1000 & 3 & 1 \\
\hline & & 3 & 1 & & & \\
\hline Cefoperazone & 1000 & 2 & 2 & - & - & - \\
\hline Cefotaxime & 1000 & 2 & 1 & - & - & - \\
\hline Ceftazidime & 1000 & 3 & 2 & 1000 & 2 & 1 \\
\hline Ceftizoxime & - & - & - & 1000 & 3 & 3 \\
\hline \multirow{7}{*}{ Ceftriaxone } & 250 & 2 & 1 & 1000 & 2 & 5 \\
\hline & 500 & 2 & 1 & & & \\
\hline & 800 & 2 & 1 & & & \\
\hline & 1000 & 2 & 12 & & & \\
\hline & & 3 & 1 & & & \\
\hline & 2000 & 2 & 2 & & & \\
\hline & & 1 & 1 & & & \\
\hline Cefuroxime & 1000 & 3 & 2 & - & - & - \\
\hline Ciprofloxacin & 200 & 2 & 1 & - & - & - \\
\hline Gentamycin & 80 & 2 & 2 & & - & - \\
\hline Levofloxacin & 750 & 1 & 5 & 750 & 1 & 3 \\
\hline \multirow[t]{4}{*}{ Meropenem } & 175 & 3 & 1 & 1000 & 3 & 1 \\
\hline & $500--$ & 3 & 1 & & & \\
\hline & 1000 & & & & & \\
\hline & 1000 & 3 & 2 & & & \\
\hline \multirow[t]{2}{*}{ Metronidazole } & 500 & 3 & 5 & - & - & - \\
\hline & 1000 & 3 & 1 & - & - & - \\
\hline Netilmicin & 100 & 2 & 1 & - & - & - \\
\hline Streptomycin & 750 & 1 & 1 & - & - & - \\
\hline
\end{tabular}

Keterangan Tabel IV:

- Kepanjangan dari singkatan dalam tabel: ICU: Intensive Care Unit; ICCU: Intensive Cardiac Care Unit

- Tanda (-) mengindikasikan jenis atau dosis regimen antibiotik tersebut tidak diberikan di ruangan tersebut

Proses analisis penggunaan antibiotik dalam penelitian ini menemukan proses de-eskalasi dilakukan sebanyak 4 kali $(13,33 \%)$ dari total 30 kali proses pergantian terapi. De-eskalasi merupakan sebuah pendekatan terapi antibiotik yang direkomendasikan karena dapat memberikan manfaat secara klinis maupun finansial, selain itu, proses tersebut terbukti tidak membahayakan pasien. Beberapa penelitian membuktikan bahwa praktek de-eskalasi tidak berdampak negative terhadap kondisi klinis pasien dan justru memberikan beberapa keuntungan, antara lain: (1) menurunkan tingkat kejadian infeksi Clostridium defficile, (2) menurunkan tingkat resistensi, dan (3) menurunkan biaya penggunaan antibiotik (Garnacho-Montero et al., 2014; Talpaert et al., 2011; Eachempati et al., 2009). Penelitian lain juga memperlihatkan hasil yang lebih spesifik yaitu, dengan dilakukannya de-eskalasi dapat menurunkan tingkat mortalitas pada pasien dengan ICU-Aquired Pneumonia (Joung et al., 2011). Dengan mempertimbangkan manfaat tersebut, de-eskalasi dapat dipertimbangkan sebagai suatu pendekatan terapi yang strategis dalam menghadapi fenomena peningkatan temuan kasus resistensi antibiotik yang tidak diiringi oleh laju penemuan antibiotik yang baru. Strategi ini sangat mungkin dilakukan pada pasien di ruang intensive care maupun pada pasien yang mengalami septic shock (Gonzalez et al,. 2013). Ironisnya, walaupun proses de-eskalasi ini memungkinkan dilakukan di ICU, praktek deeskalasi di lapangan masih kurang diterapkan secara holistik. Hasil penelitian ini sejalan dengan penelitian Heenen et al., (2012) yang menunjukkan bahwa de-eskalasi antibiotik masih sangat 
sedikit dilakukan pada prakteknya secara nyata. Salah satu faktor penting dalam melakukan proses deeskalasi adalah dilakukannya kultur spesimen pada pasien yang terindikasi mengalami infeksi sebelum memberikan terapi antibiotik empiris. Kultur bakteri merupakan tahapan yang penting dalam tata laksana infeksi baik untuk menentukan diagnosis dan menentukan terapi antibiotik yang dibutuhkan. Ironisnya, dalam penelitian ini hanya ditemukan 3 pasien $(3,14 \%)$ yang dilakukan kultur dari total 42 pasien yang mendapatkan antibiotik. Melalui hasil kultur maka terapi antibiotik definit yang umumnya menggunakan antibiotik dengan spektrum aktivitas yang lebih sempit (narrow spectrum antibiotics) dapat dilakukan. Selain berdampak pada penurunan risiko resistensi, penggunaan antibiotik dengan spektrum yang lebih sempit dapat menurunkan biaya yang dibutuhkan karena harganya yang relatif lebih murah dibandingkan dengan antibiotik yang memiliki spektrum aktivitas yang luas (broad spectrum antibiotics). Penelitian lebih lanjut yang bertujuan untuk menggali faktor-faktor yang menyebabkan jarangnya praktek de-eskalasi di ICU perlu dilakukan sebagai upaya untuk mengoptimalkan pelaksanaan praktek de-eskalai dikemudian hari.

Analisis terkait biaya penggunaan antibiotik pada penelitian ini memperlihatkan hasil yang bervariasi (Tabel V). Rata-rata pengeluaran biaya oleh pasien untuk pembelian antibiotik sebesar Rp. 459.492,-. Biaya terbesar yang dikeluarkan adalah sebesar Rp. 8.314.914,-- sedangkan biaya terkecil adalah sebesar Rp. 15.852,-. Variasi biaya disebabkan oleh berbagai hal, antara lain: (1) durasi penggunaan antibiotik, (2) golongan dan jenis antibiotik yang digunakan, (3) penggunaan antibiotik bentuk generik ataupun paten, (4) keadaan pasien dan (5) bentuk sediaan antibiotik yang diberikan. Hasil simulasi dengan membandingkan antara biaya yang dikeluarkan untuk penggunaan antibiotik dan biaya BPJS (Badan Penyelenggara Jaminan Sosial) didapatkan hasil persentase biaya penggunaan antibiotik yang tertinggi adalah $93,52 \%$ sedangkan yang paling rendah adalah $0,57 \%$ (dilihat pada tarif kelas 3). Hasil simulasi tersebut mengindikasikan terdapat potensi pengeluaran biaya kesehatan yang cukup besar karena masih terdapat biaya lain yang harus ditanggung, antara lain: biaya alat kesehatan, kamar, jasa dokter, dan tes-tes laboratorium. Apabila biaya yang dibutuhkan pasien melebihi dari anggaran yang dapat diklaim, rumah sakit akan menanggung beban kelebihan tersebut.

Analisis kesesuaian antibiotik dilakukan pada 15 pasien yang mendapatkan diagnosis infeksi saja. Terdapat 4 pasien $(26,67 \%)$ yang mendapatkan terapi antibiotik yang tepat atau sesuai secara keseluruhan. Detail dari analisis kesesuaian penggunaan antibiotik dijabarkan pada tabel VI. Dari antara 42 pasien dalam penelitian ini, hanya 3 pasien $(7,14 \%)$ yang dilakukan kultur bakteri. Hasil analisis dari penelitian ini menunjukkan bahwa hanya 4 orang $(26,67 \%)$ dari total 12 orang dengan diagnosis infeksi dan tidak memiliki hasil pemeriksaan kultur menerima terapi antibiotik yang tepat. Dalam hal ini, hasil analisis ketepatan terapi antibiotik tidak berbeda jauh dengan penelitian lain yang dilakukan di Jakarta, yang menunjukkan 74,03\% terapi empirik dan 78,51\% terapi definitif pada pasien ICU tidak tepat (Luciana et al., 2015). Ketepatan pemberian antibiotik harus selalu dipastikan sejak awal pemberian terapi empirik. Jenis antibiotik yang diberikan harus memiliki aktivitas yang memungkinkan untuk membunuh bakteri yang diduga menjadi penyebab infeksi. Terapi empirik yang tepat juga memberikan efek jangka panjang yaitu dapat menurunkan semua penyebab kematian secara signifikan dan memperpendek lama tinggal di rumah sakit (Paul et al., 2010; Zilberberg et al., 2008). 
Tabel V. Data biaya penggunaan antibiotik dan persentase biaya terhadap tarif INA-CBG

\begin{tabular}{|c|c|c|c|c|}
\hline Diagnosis & $\begin{array}{c}\text { Biaya Antibiotik } \\
\text { (Rp) }\end{array}$ & $\begin{array}{c}\text { Tarif kelas } 3 \\
(\%)\end{array}$ & $\begin{array}{c}\text { Tarif Kelas } 2 \\
(\%)\end{array}$ & $\begin{array}{c}\text { Tarif Kelas } 1 \\
(\%)\end{array}$ \\
\hline Multi diagnosis & $757.027,-$ & $\begin{array}{l}5.997 .435,- \\
\quad(12,62)\end{array}$ & $\begin{array}{l}7.196 .922,- \\
(10,52)\end{array}$ & $\begin{array}{l}8.396 .409,- \\
(9,02)\end{array}$ \\
\hline $\begin{array}{l}\text { Susp. Sepsis + } \\
\text { Pneumonia + ISK }\end{array}$ & $553.948,-$ & $\begin{array}{c}8.890 .831,- \\
(6,23)\end{array}$ & $\begin{array}{c}10.668 .997,- \\
(5,19)\end{array}$ & $\begin{array}{c}12.447 .163,- \\
(4,45)\end{array}$ \\
\hline $\begin{array}{l}\text { Sepsis + Pneumonia + } \\
\text { MODS }\end{array}$ & $1.860 .975,-$ & $\begin{array}{c}8.890 .831,- \\
(20,93)\end{array}$ & $\begin{array}{c}10.668 .997,- \\
(17,44)\end{array}$ & $\begin{array}{c}12.447 .163,- \\
(14,95)\end{array}$ \\
\hline Pneumonia & 98.992,- & $\begin{array}{c}8.890 .831,- \\
(1,11)\end{array}$ & $\begin{array}{c}10.668 .997,- \\
(0,93)\end{array}$ & $\begin{array}{c}12.447 .163,- \\
(0,80)\end{array}$ \\
\hline Pneumonia + Sepsis & 8.314.914,- & $\begin{array}{l}8.890 .831,- \\
\quad(93,52)\end{array}$ & $\begin{array}{c}10.668 .997,- \\
(77,94)\end{array}$ & $\begin{array}{c}12.447 .163,- \\
(66,80)\end{array}$ \\
\hline Infeksi Bakterial & $70.640,-$ & $\begin{array}{c}4.497 .738,- \\
(1,57)\end{array}$ & $\begin{array}{c}5.397 .286,- \\
(1,31)\end{array}$ & $\begin{array}{c}6.296 .833,- \\
(1,21)\end{array}$ \\
\hline $\begin{array}{l}\text { Susp. Sepsis menjadi } \\
\text { Sepsis Neonatus }\end{array}$ & 173.960,- & $\begin{array}{c}3.989 .552,- \\
(4,36)\end{array}$ & $\begin{array}{c}\text { 4.787.462,-- } \\
(3,63)\end{array}$ & $\begin{array}{c}5.585 .372,- \\
(3,11)\end{array}$ \\
\hline Sepsis & $44.150,-$ & $\begin{array}{l}3.989 .552,- \\
\quad(1,11)\end{array}$ & $\begin{array}{l}\text { 4.787.462,-- } \\
\quad(0,92)\end{array}$ & $\begin{array}{l}5.585 .372,- \\
(0,79)\end{array}$ \\
\hline Susp. TB Paru & $34.212,-$ & $\begin{array}{l}5.997 .435,- \\
(0,57)\end{array}$ & $\begin{array}{c}7.196 .922,- \\
(0,48)\end{array}$ & $\begin{array}{l}8.396 .409,- \\
(0,41)\end{array}$ \\
\hline Risiko Infeksi & $70.640,-$ & No data & No data & No data \\
\hline BP & $2.083 .774,-$ & $\begin{array}{l}8.890 .831,- \\
(23,44)\end{array}$ & $\begin{array}{c}10.668 .997,- \\
(19,53)\end{array}$ & $\begin{array}{c}12.447 .163,- \\
(16,74)\end{array}$ \\
\hline Susp. Encephalitis & $1.862 .718,-$ & No data & No data & No data \\
\hline Pneumonia & $1.428 .300,-$ & $\begin{array}{c}8.890 .831,- \\
(16,06)\end{array}$ & $\begin{array}{c}\text { 10.668.997,- } \\
(13,39)\end{array}$ & $\begin{array}{c}12.447 .163,- \\
(11,47)\end{array}$ \\
\hline Risiko Infeksi & $79.470,-$ & No data & No data & No data \\
\hline Risiko Infeksi & $52.980,-$ & No data & No data & No data \\
\hline GEA + Susp. BP & $295.584,-$ & $\begin{array}{c}8.890 .831,- \\
(3,32)\end{array}$ & $\begin{array}{c}10.668 .997,- \\
(2,77)\end{array}$ & $\begin{array}{c}12.447 .163,- \\
(2,37)\end{array}$ \\
\hline Sepsis + MODS & $791.044,-$ & $\begin{array}{l}3.989 .552,- \\
\quad(19,83)\end{array}$ & $\begin{array}{l}4.787 .462,- \\
\quad(16,52)\end{array}$ & $\begin{array}{l}5.585 .372,- \\
\quad(14,16)\end{array}$ \\
\hline Risiko Infeksi & $52.980,-$ & No data & No data & No data \\
\hline Susp. Selulitis & $634.800,-$ & No data & No data & No data \\
\hline Risiko Infeksi & $104.400,-$ & No data & No data & No data \\
\hline Infeksi Bakterial & $52.890,-$ & $\begin{array}{c}4.497 .738,- \\
(1,18)\end{array}$ & $\begin{array}{c}5.397 .286,- \\
(0,98)\end{array}$ & $\begin{array}{l}6.296 .833,- \\
(0,84)\end{array}$ \\
\hline Sepsis & $1.110 .900,-$ & $\begin{array}{l}3.989 .552,- \\
\quad(27,85)\end{array}$ & $\begin{array}{l}\text { 4.787.462,-- } \\
\quad(23,20)\end{array}$ & $\begin{array}{l}5.585 .372,- \\
(19,89)\end{array}$ \\
\hline Spondilitis TB & $278.300,-$ & $\begin{array}{c}5.997 .435,- \\
(4,64)\end{array}$ & $\begin{array}{c}7.196 .922,- \\
(3,87)\end{array}$ & $\begin{array}{c}8.396 .409,- \\
(3,31)\end{array}$ \\
\hline $\begin{array}{l}\text { Susp. Sepsis + } \\
\text { Encephalitis }\end{array}$ & $34.212,-$ & $\begin{array}{l}3.989 .552,- \\
\quad(0,86)\end{array}$ & $\begin{array}{c}4.787 .462,- \\
(0,71)\end{array}$ & $\begin{array}{c}5.585 .372,- \\
(0,61)\end{array}$ \\
\hline $\begin{array}{l}\text { Susp. Pneumonia } \\
\text { menjadi Pneumonia }\end{array}$ & $458.080,-$ & $\begin{array}{c}8.890 .831,- \\
(5,15)\end{array}$ & $\begin{array}{c}10.668 .997,- \\
(4,29)\end{array}$ & $\begin{array}{c}12.447 .163,- \\
(3,68)\end{array}$ \\
\hline Sepsis + Pneumonia & $544.456,-$ & $\begin{array}{l}8.890 .831,- \\
(6,12)\end{array}$ & $\begin{array}{c}\text { 10.668.997,- } \\
(5,10)\end{array}$ & $\begin{array}{c}12.447 .163,- \\
(4,37)\end{array}$ \\
\hline Pneumonia & $634.800,-$ & $\begin{array}{l}8.890 .831,- \\
\quad(7,14)\end{array}$ & $\begin{array}{c}10.668 .997,- \\
(5,95)\end{array}$ & $\begin{array}{c}12.447 .163,- \\
(5,10)\end{array}$ \\
\hline
\end{tabular}


Keterangan Tabel V:

i. Multi diagnosis = TB Paru Millier + Meningoencephalitis + Limpadenitis TB + Sepsis

ii. Kepanjangan pada tabel di atas: Susp.: dugaan; TB: Tuberkulosis; BP: Bronkopneumonia; GEA: Gastroenteritis Akut; ISK: Infeksi Saluran Kemih; MODS: Mutiple Organ Dysfunction Syndrome; DHF: Dengue Haemorrogic Fever; ICU: Intensive Care Unit; ICCU: Intensive Cardiac Care Unit; NICU: Neonatal Intensive Care Unit; AB: Antibiotik. \%: Nilai persentase biaya yang digunakan dibandingkan dengan tarif INA-CBGs

iii. Rumus untuk mendapatkan persentasi biaya yang digunakan untuk biaya antibiotik:

$$
\% \text { nilai }=\frac{\text { Biaya antibiotik pasien }}{\text { Biaya JKN berdasrakan INA-CBGs}} \times 100 \%
$$

a) Menggunakan ceftazidime 14 sediaan, levofloxacin 6 sediaan, metronidazole 1 sediaan; b) Menggunakan levofloxacin 2 sediaan; c) Menggunakan ampicillin 8 sediaan; d) Menggunakan ampicillin 12 sediaan dan cloxacillin (Meixam®) 2 sediaan; e) Menggunakan ampicillin 5 sediaan; f) Menggunakan ceftriaxone 2 sediaan; g) Menggunakan ceftriaxone 8 sediaan dan meropenem 2 sediaan; h) Menggunakan ampicillin 6 sediaan; i) Menggunakan cefoperazone 4 sediaan; j) Menggunakan ceftriaxone 1 sediaan; k) Menggunakan ceftriaxone 3 sediaan, levofloxacin 5 sediaan dan ceftazidime 9 sediaan; 1) Menggunakan levofloxacin 11 sediaan; m) Menggunakan ceftriaxone (Cefxon®) 1 sediaan; n) Menggunakan meropenem 8 sediaan.

Tabel VI. Data analisis kesesuaian penggunaan antibiotik pasien ICU dan ICCU

\begin{tabular}{|c|c|c|}
\hline Kategori & Pasien (orang) & Persentase $(\%)$ \\
\hline Pasien dengan kultur & 3 & 20,00 \\
\hline Tidak tepat dengan catatan ${ }^{\mathrm{a}}$ & 3 & 20,00 \\
\hline Pasien tanpa kultur & 12 & 80,00 \\
\hline Seluruh terapi AB tepat & 4 & 26,67 \\
\hline - Tepat & 4 & 26,67 \\
\hline \multicolumn{3}{|l|}{ Sebagian terapi AB tepat } \\
\hline - Tidak diberikan kombinasi yang bersifat sinergis ${ }^{\mathrm{b}}$ & 4 & 26,67 \\
\hline - Tidak tepat dengan catatan ${ }^{c}$ & 1 & 6,66 \\
\hline Terapi AB tidak tepat ${ }^{\mathrm{d}}$ & 3 & 20,00 \\
\hline Total & 15 & 100,00 \\
\hline
\end{tabular}

Keterangan Tabel VI:

i. Untuk 1 orang pasien yang mengalami perubahan diagnosis penggunaan antibiotik dianggap tidak tepat apabila ada ketidaktepatan pada salah satu diagnosis.

a) 2 pasien diberikan antibiotik yang melebihi yang dibutuhkan, 1 pasien pemberian antibiotiknya terlambat dan dengan dosis yang kurang; b) diagnosis pneumonia hanya diberi levofloxacin $(n=1)$, diagnosis pneumonia hanya diberikan ceftriaxone $(\mathrm{n}=2)$, dan diagnosis pneumonia hanya diberikan meropenem $(\mathrm{n}=1)$; c) 1 pasien diberikan antibiotik yang melebihi yang dibutuhkan; d) diagnosis dugaan meningitis diberikan kombinasi cefuroxime dan streptomycin; Diagnosis dugaan tuberkulosis diberikan ceftriaxone; Diagnosis spondilitis tuberkulosis diberikan cefoperazone

Pada penelitian ini hanya ditemukan pencampuran antara antibiotik dengan pelarut dan tidak ditemukan antibiotik yang dicampur dengan obat lain. Hasil analisis ketercampuran menunjukkan sebagian besar campuran antibiotik dengan pelarut diklasifikasikan sebagai kompatibel, yaitu sebanyak 37 pencampuran $(86,04 \%)$. Pada penelitian ini masih ditemukan campuran antibiotik dengan pelarut yang masih tanpa informasi (no information) yaitu 6 campuran (13,96\%) dari total 43 pencampuran pada ruang ICU dan ICCU. Di ruang ICCU terdapat 10 pencampuran antibiotik dan pelarut, dan seluruhnya $(100,00 \%)$ disimpulkan kompatibel. Hasil dari penelitian ini selaras dengan penelitian lain yang dilakukan di ICU yang mengemukakan masih banyak campuran antara antibiotik dengan pelarut yang tidak ditemukan informasi. Pada penelitian sebelumnya menyebutkan bahwa pencampuran antara senyawa obat dengan pelarut pada pasien dewasa dan anak yang tidak diketahui informasi kompatibilitas dan inkompatibilitasnya sebesar 19,68\% dan 30,16\%, secara berturut-turut (Dwijayanti et al., 2016). Penelitian kompatibilitas sediaan intravena untuk campuran yang diklasifikasikan no information perlu dilakukan sebagai upaya untuk memaksimalkan efek terapi pasien. Kompatibilitas 
antibiotik perlu mendapatkan perhatian yang lebih besar dalam memaksimalkan terapi yang diberikan kepada pasien, dan terutama dalam hal ini adalah pada pasien dengan keadaan kritis. Sebuah penelitian terbaru, menunjukkan bahwa pada pencampuran antara piperacillin-tazobactam dengan vancomycin hanya kompatibel bila konsentrasi dari vancomycin adalah sebesar $5 \mathrm{mg} / \mathrm{mL}$. Sedangkan bila konsetrasinya dinaikkan menjadi $10 \mathrm{mg} / \mathrm{mL}$ atau $15 \mathrm{mg} / \mathrm{mL}$, akan terjadi inkompatibilitas pada campuran tersebut (Meyer et al., 2017).

Penggunaan antibiotik di ruang intensive care merupakan hal yang patut menjadi perhatian. Penelitian ini merupakan penelitian pertama yang mengkaji profil penggunaan, kesesuaian, dan kompatibilitas pemberian antibiotik di ICU. Terdapat 3 publikasi lain terkait analisis penggunaan antibiotik di bangsal ICU. Penelitian yang dilakukan oleh Adisasmito and Tumbelaka (2006) meneliti korelasi antara penggunaan antibiotik dengan tingkat resistensi bakteri gram negatif di bangsal ICU anak tanpa mengidentifikasi profil ketepatan dan kompatabilitas pemberian terapi antibiotik. Penelitian lain oleh Anggriani et al. (2013) melihat penggunaan antibiotik pasien kanker di ICU yang dinyatakan dalam defined daily dose (DDD). Sedangkan penelitian yang

terakhir oleh Luciana et al. (2015) melihat kesesuaian terapi antibiotik baik terapi empirik maupun terapi definit tanpa melakukan analisis kompatibilitas antibiotik dengan sediaan intravena yang lain. Pada penelitian ini, profil penggunaan antibiotik dari berbagai sudut, mulai dari kesesuaian, kompatibilitas, biaya penggunaan antbiotik dan proses pergantian terapi (proses eskalasi dan deeskalasi) dibahas secara menyeluruh.

\section{KESIMPULAN}

Penggunaan antibiotik di ruang intensive care tempat penelitian ini dilakukan masih terdapat banyak peluang perbaikan untuk meminimalkan kegagalan terapi pasien, risiko terjadinya resistensi, dan risiko peningkatan biaya kesehatan. Tidak lebih dari $30 \%$ pasien dengan diagnosis infeksi mendapat terapi antibiotik yang diklasifikasikan tepat secara keseluruhan meliputi tepat jenis, dosis, dan frekuensi. Minimnya impementasi praktek de-eskalasi dan masih dijumpainya pemberian antibiotik bersamaan dengan pelarut yang masih belum jelas status kompatibilitasnya juga menuntut adanya proses perbaikan pemberian antibiotik di ICU. Peluang perbaikan tersebut perlu mendapat perhatian dari berbagai pihak di era implementasi JKN dengan mempertimbangkan temuan dalam penelitian ini terkait biaya penggunaan antibiotik yang dapat mencapai lebih dari $90 \%$ dari biaya klaim BPJS. Tanpa ada intervensi baik dari pemerintah maupun rumah sakit, bukan tidak mungkin jika penggunaan antibiotik menjadi faktor utama penyebab tidak terkendalinya biaya kesehatan nasional.

\section{DAFTAR PUSTAKA}

Adisasmito, A.W., \& Tumbelaka, A.R., 2006, Penggunaan antibiotik khususnya pada infeksi bakteri gram negatif di ICU anak RSAB Harapan Kita, Sari Pediatri. 8(2):127-34.

Anggriani, Y., Banun, A., Erliana., 2013, Evaluasi penggunaan antibiotika di ruang HCU dan ruang ICU rumah sakit kanker "Dharmais" Februari-Maret 2012, Jurnal Ilmu Kefarmasian Indonesia. 11 (2):182-90.

Bass, S N, Bauer, S R, Neuner, E A, Lam, S W., 2015, Impact of Combination Antimicrobial Therapy on Martility Risk of Critically III Patients with Carbapenem-Resistant Bacteremia, Antimicrobial Agents and Chemotherapy, 59(7): 3748-53.

Cucu, A., Nica, M., Ceausu, E., Cioran, N., 2014, Antimicrobial resistance profile in infectious disease hospital intensive care unit, FARMACIA. 62(4):767-76.

Dulhunty, J.M., Roberts, J.A., Davis, J.S., Webb, S.A., Bellomo, R., Gomersall, C., et al., 2013, Continuous infusion of beta-lactam antibiotics in severe sepsis: a multicenter double-blind, randomized controlled trial, Clin Infect Dis. 56(2):236-44.

Dwijayanti, S., Irawati, S., Setiawan, E., 2016, Profil kompatibilitas sediaan obat intravena dengan pelarut pada pasien intensive care unit, Jurnal Farmasi Klinik Indonesia. 5(2): 84-97. 
Eachempati, S.R., Hydo, L.J., Shou, J., Barie, P.S., 2009, Does de-escalation of antibiotic therapy for ventilator-associated pneumonia affect the likelihood of recurrent pneumonia or mortality in critically ill surgical patients?, J Trauma. 66(5):1343-8.

Garnacho-Montero, J., Gutiérrez-Pizarraya, A., Escoresca-Ortega, A., Corcia-Palomo, Y., FernándezDelgado, E., Herrera-Melero, I., et al., 2014, De-escalation of empirical therapy is associated with lower mortality in patients with severe sepsis and septic shock, Intensive Care Med. 40(1):32-40.

Goncalves-Pereira, J., \& Povoa, P., 2011, Antibiotics in critically ill patients: a systematic review of the pharmacokinetics of $\beta$-lactams. Crit Care. 15(5):R206.

Gonzalez, L., Cravoisy, A., Barraud, D., Conrad, M., Nace, L., Lemarié, J., et al., 2013, Factors influencing the implementation of antibiotic de-escalation and impact of this strategy in critically ill patiens, Crit Care. 17(4):R140.

Hanberger, H., Walther, S., Leone, M., Barie, P.S., Rello, J., Lipman, J., et al., 2011, Increased mortality associated with methicillin-resistant Staphylococcus aureus (MRSA) infection in the intensive care unit: result from The EPIC II study, Int J Antimicrob Agents. 38(4):331-5.

Heenen, S., Jacobs, F., Vincent, J.L., 2012, Antibiotic strategies in severe nosocomial sepsis: why do we not de-escalate more often?, Crit Care Med. 40(5):1404-9.

Joung, M K, Lee, J A, Moon, S Y, Cheong, H S, Joo, E J, Ha, Y E., et al, 2011, Impact of Deescalation Therapy on Clinical Outcomes for Intensive Care Unit-Acquired Pneumonia, Critical Care, 11: R79.

Khan, R.A., Bakry, M.M., Islahudin, F., 2015, Appropriate antibiotic administration in critically ill patients with pneumonia, Indian J Pharm Sci. (3): 299-305.

Luciana, Andrajati, R, Rianti, A, Khan, A H., 2015, Rational Antimicrobial Use in an Intensive Care Unit in Jakarta, Indonesia: A Hospital-Based, Cross-Sectional Study, Tropical Journal of Pharmaceutical Research, 14(4): 707-14.

Luciana, Andrajati, R., Rianti, A., Khan, A.H., 2015, Rational antimicrobial use in an intensive care unit in Jakarta, Indonesia: a hospital-based, cross-sectional study, Trop J Pharm Res. 14(4):70714.

Marcon, A.P., Gamba, M.A., Vianna, L.A., 2006, Nosocomial diarrhea in the intensive care unit, Braz J Infect Dis. 10(6):384-9.

Marquet, K., Liesenborgs, A., Bergs, J., Vleugels, A., Claes, N., 2015, Incidence and outcome of inappropriate in-hospital empiric antibiotics for severe infection: a systematic review and metaanalysis, Crit Care. 19:63.

McKinnon, P.S., Paladino, J.A., Schentag, J.J., 2008, Evaluation of area under the inhibitory curve (AUIC) and time above the minimum inhibitory concentration $(\mathrm{T}>\mathrm{MIC})$ as predictors of outcome for cefepime and ceftazidime in serious bacterial infections, Int $J$ Antimicrob Agents. 31(4):345-51.

Meyer, K., Santarossa, M., Danziger, L.H.. Wenzler, E., 2017, Compatibility of CeftazidimeAvibactam, Ceftoloxane-Tazobactam, and Piperacillin-Tazobactam with Vancomycin in Dextrose 5\% in Water, Hospital Pharmacy, 52: 221.

Owens, R.C. Jr., Donskey, C.J., Gaynes, R.P., Loo, V.G., Muto, C.A., 2008, Antimicrobial-associated risk factors for Clostridium defficile, Clin Infect Dis. 46 Suppl 1:S19-31.

Paul, M., Kariv, G., Goldberg, E., Raskin, M., Shaked, H., Hazzan, R., et al., 2010, Importance of appropriate empirical antibiotic therapy for methicillin-resistant Staphylococcus aureus bacteraemia, J Antimicrob Chemother. 65(12):2658-65.

Radji, M, Fauziah, S, Aribinuko, N., 2011, Antibiotic Sensitivity Pattern of Bacterial Pathogens in the Intensive Care Unit of Fatmawati Hospital, Indonesia, Asian Pacific Journal of Tropical Biomedicine, 1(1): 39-42.

Roberts, J.A., \& Lipman, J., 2009, Pharmacokinetic issues for antibiotics in the critically ill patient, Crit Care Med. 37(3):840-51. 
Rubio-Terres, C., Garau, J., Grau, S., Martinez-Martinez, L., 2010, Cost of bacteraemia caused by methicillin-resistant vs. methicillin-susceptible Staphylococcus aureus in Spain: a retrospective cohort study, Clin Microbiol Infect. 16(6): 722-8.

Talpaert, M.J., Gopal Rao, G., Cooper, B.S., Wade, P., 2011, Impact of guidelines and enhanced antibiotic stewardship on reducing broad-spectrum antibiotic usage and its effect on incidence of Clostridium difficile infection, J Antimicrob Chemother. 66(9):2168-74.

Trissel, L.A., 2013, Handbook on injectable drugs, $17^{\text {th }}$ edition. Bethesda: American Society of Health-System Pharmacists.

Vincent, J L, Bassetti, M, Francois, B, Karam, G, Chastre, J, Torres, A., 2016, Advances in Antibiotic Therapy in The Critically Ill, Critical Care, 20: 133.

Williams, D.J., Hall, M., Shah, S.S., Parikh, K., Tyler, A., Neuman, M.I., et al., 2013, Narrow vs broad-spectrum antimicrobial therapy for children hospitalized with pneumonia, Pediatrics. 132(5): e1141-e1148.

Zilberberg, M.D., Shorr, A.F., Micek, S.T., Mody, S.H., Kollef, M.H., 2008, Antimicrobial therapy escalation and hospital mortality among patients with health-care-associated pneumonia: a single-center experience, Chest. 134(5):963-8. 